\title{
Testicular Infarction
}

National Cancer Institute

\section{Source}

National Cancer Institute. Testicular Infarction. NCI Thesaurus. Code C27617.

Ischemic necrosis of the testis usually caused by torsion of the spermatic cord, trauma, or severe epididymo-orchitis. 